\title{
Effect of Inoculum Density and Methods of Inoculation on the Development of Bacterial Leaf Spot of Bottle Gourd and Pumpkin caused by Xanthomonas cucurbitae
}

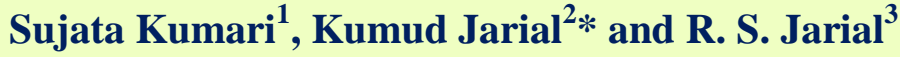 \\ Department of Plant Pathology, College of Horticulture and Forestry, \\ Neri, Hamirpur (HP) -177001, India \\ *Corresponding author
}

Keywords

Bacterial leaf spot, Xanthomonas cucurbitae, inoculum density, bottle gourd and pumpkin

\section{Article Info}

Accepted:

18 May 2020

Available Online:

10 June 2020

\section{A B S T R A C T}

Bacterial leaf spot caused by Xanthomonas cucurbitae is one of the important diseases of bottle gourd and pumpkin and is gaining momentum in the sub-tropical zone of Himachal Pradesh. Studies were conducted under artificial inoculation conditions to standardize the inoculum concentration and method of inoculation for the development of disease. The bacterial concentration was standardized with the help of a growth curve of both bottle gourd and pumpkin isolates of $X$ cucurbitae with time and a sigmoid curve was obtained in both the isolates in which the bacterial concentration reached its maximum $\left(10^{7} \mathrm{cfu} / \mathrm{ml}\right)$ after 96 days of inoculation and then declined. Studies on effect of different inoculum densities of causal bacterium on disease development revealed that an inoculum concentration of $10^{8} \mathrm{cfu} / \mathrm{ml}$ of both the isolates resulted in minimum incubation period ( 2 and 4 days) and maximum mean disease severity (38.89 and $42.00 \%$ ) in both bottle gourd and pumpkin plants, respectively. Among various methods of inoculation with both isolates, syringe method of inoculation resulted in minimum incubation period ( 2.33 and 3.33 days) and maximum disease severity (46.33 and $37.97 \%$ ) in both bottle gourd and pumpkin, respectively followed by pin prick method of inoculation.

\section{Introduction}

The family cucurbitaceae is a medium sized family consisting of about 120 genera and more than 800 species collectively known as cucurbits, distributed predominantly in the tropical and subtropical regions of the new and old world (Ajuru and Nmom, 2017). The cucurbitaceous crops are rich in nutritional as well as medicinal value (Khulakpam et al.,
2015). Gourds, pumpkins and squashes are harvested worldwide in an area of 1.99 million ha with an annual production of 26.48 million metric tonnes (Anonymous, 2016).

In India, bottle gourd and pumpkin are two important cucurbits grown as commercial vegetables crops. Bottle gourd is grown in an area of 1.57 lakh hectare with an annual production of 25.72 lakh tonnes. 
The area under pumpkin is 72 thousand hectare with an annual production of 15.82 lakh tonnes (Anonymous, 2017). Like all other crops, cucurbits are also attacked by a wide array of pathogens, out of which bacterial leaf spot caused by $X$. cucurbitae (Bryan) Vauterin et al., (Syn.: X. campestris pv. cucurbitae) is one of the important emerging pathogen leading to heavy crop losses especially to bottle gourd, pumpkin and squashes (Babadoost and Ravanlou, 2012 and Jarial et al., 2015). Significant losses have been reported in different cucurbits due to this disease. In bottle gourd, significant (20-70\%) losses have been reported by Larazev (2009), Jarial et al., (2011) and Basit et al., (2014) while in pumpkin, Salamanca (2014) reported up to 90 per cent losses.

The bacteria presumably persist as epiphytes on the plant surface before they enter the plant via natural openings such as hydathodes, stomata or wounds. Inside the plant tissue, Xanthomonas spp. multiply either locally in the intercellular space or colonize the xylem vessels and then spread systemically within the plant (Buttner and Bonas, 2010). An understanding of impact of inoculums concentration on any plant infection is essential to understand any host pathogen interaction. A suitable seedling inoculation method for disease development would be highly desirable for defining conditions that allow optimal infection (Mitchell, 1978).

Many workers have conducted pathogenicity experiments on artificial inoculation of this bacterium by using different methods of inoculations and various inoculum densities (Robbs et al., 1972 Taketani et al., 1976; ElHendawy, 1999 Pruvost et al., 2008; Babadoost and Zitter, 2009 and Jarial et al., 2011), but proper studies on appropriate method of inoculation as well as optimum inoculum density have never been conducted.
Therefore, the present investigations were conducted with an objective to standardize the optimum inoculum concentration and method of inoculation for disease development under artificial conditions.

\section{Materials and Methods}

Infected leaves of bottle gourd and pumpkin exhibiting characteristics symptoms were brought to laboratory and pathogen was isolated and purified by following standard procedures. The isolated colonies of the associated bacterium were maintained on nutrient agar slants for further experiments and the pathogen was identified on the basis of cultural and biochemical characters as suggested by Society of American Bacteriologists (1957) and Schhad and Stall (1988) and further confirmed by pathogenicity tests.

\section{Standardization of $X$. cucurbitae concentration $(\mathrm{cfu} / \mathrm{ml})$ with time}

To standardize inoculum density of $X$. cucurbitae (for both isolates) in terms of colony forming units per millilitre (cfu/ml) with time, $72 \mathrm{~h}$ old bacterial colonies from NSA slant of both the isolates (bottle gourd and pumpkin) were suspended in $50 \mathrm{ml}$ of NSB to make the starter culture and pour plated to check its concentration (cfu/ml). Simultaneously, $1 \mathrm{ml}$ suspension from this starter culture was inoculated in nine $150 \mathrm{ml}$ capacity Erlenmeyer flasks containing $50 \mathrm{ml}$ nutrient sodium chloride broth and incubated for different durations viz., 0, 6, 12, 24, 48, $72,96,120$ and 144 hours of incubation. One $\mathrm{ml}$ suspension from respective flasks was serially diluted and pours plated on nutrient sodium chloride agar medium to record the colony forming units per millilitre $(\mathrm{cfu} / \mathrm{ml})$. A growth curve was further plotted in terms of natural log values of colony forming units per millilitre (ln $\mathrm{cfu} / \mathrm{ml})$ with time (h). 
Effect of different inoculum density on disease development

An experiment was conducted as completely randomized block design in which bacterial suspension having different concentrations viz., $10^{4}, 10^{5}, 10^{6}, 10^{7}, 10^{8}$ and $10^{9} \mathrm{cfu} / \mathrm{ml}$ of both isolates were adjusted with regard to growth curve obtained in 2.2 and the suspension of each concentration was inoculated on 1 month old bottle gourd and pumpkin seedlings through leaf margin. Inoculated plants were covered with polythene bags internally sprayed with sterile distilled water to maintain the appropriate relative humidity and incubated at room temperature. Each treatment was replicated thrice. The data were recorded in terms of incubation period (days) and disease severity (\%). Observations on disease severity were regularly recorded at 2 days interval starting from the day of symptoms development and apparent infection rate (per unit per day) as well as AUDPC were further also calculated as per the formulae given by Van der Plank (1963) and Shanner and Finney (1977), respectively.

Apparent infection rate was calculated by following formula:-

$\ln \mathrm{x}_{2} / 1-\mathrm{x}_{2}=\ln \mathrm{x}_{1} / 1-\mathrm{x}_{1}+\mathrm{r}\left(\mathrm{t}_{2}-\mathrm{t}_{1}\right)$

(Van der Plank, 1963)

where;

$r$ is apparent infection rate (per unit per day) and $\mathrm{x}_{1}$ and $\mathrm{x}_{2}$ are disease proportions at dates $t_{1}$ and $t_{2}$, respectively.

AUDPC was calculated as follows:-

$\operatorname{AUDPC}=\sum_{\mathrm{i}=1}^{\mathrm{n}}\left\{\left(\mathrm{Y}_{\mathrm{i}+1}\right)+\mathrm{Yi} / 2\right\}\left(\mathrm{t}_{\mathrm{i}+1}-\mathrm{t}_{\mathrm{i}}\right)$

(Shanner and Finney, 1977) where;

$Y i$ and $Y_{i+1}$ are disease proportions at time $t_{i}$ and $t_{i+1}$, respectively and $n$ is total number of observations.

\section{Effect of different methods of inoculation on disease development}

The effect of different methods of inoculation on disease development was studied by inoculating a standard concentration $\left(10^{8}\right.$ $\mathrm{cfu} / \mathrm{ml}$ for bottle gourd and pumpkin isolate) of bacterial suspension obtained in 2.2 on 1 month old seedlings of bottle gourd and pumpkin. Following different methods of inoculation were studied to record the data in terms of the incubation period and disease severity and further calculating apparent infection rate and AUDPC.

\section{Inoculation at leaf margins}

Drops of standard bacterial suspension were placed on the margins of the leaves of bottle gourd and pumpkin plants with the help of dropper.

\section{Swab inoculation}

The leaves of healthy bottle gourd and pumpkin plants were swabbed at both surfaces with sterilized cotton swab soaked in standard bacterial suspension.

\section{Pin prick method}

The leaves of healthy bottle gourd and pumpkin plants were pricked with the help of a sterilized paper pin and standard bacterial suspension was swabbed on them with the help of cotton.

\section{Syringe inoculation}

Standard bacterial suspension was injected into the mid-rib of the leaves and in the stem 
of healthy bottle gourd and pumpkin plants with the help of sterilized hypodermic syringe.

\section{Spray inoculation}

The leaves of healthy bottle gourd and pumpkin plants were sprayed with sterilized sprayer containing standard bacterial suspension.

\section{Results and Discussion}

The colony characteristics of both pathogen isolates were observed on nutrient sodium chloride agar medium. The colonies were mucoid, circular, smooth textured and yellow in colour (P). On the bases of cultural and biochemical tests, the pathogen was identified as Xanthomonas cucurbitae. during pathogenicity tests, incubation periods of 2 and 4 days, respectively were recorded in case of bottle gourd and pumpkin.

\section{Standardization of $X$. cucurbitae concentration $(\mathrm{cfu} / \mathrm{ml})$ with time}

The concentration of bacteria (both isolates) in culture was recorded to be $10^{4} \mathrm{cfu} / \mathrm{ml}$ which increased logarithmically with the time and reached its maximum $\left(10^{9} \mathrm{cfu} / \mathrm{ml}\right)$ after $72 \mathrm{~h}$ of incubation. Thereafter, the concentration of both isolates in the culture started declining and it decreased to $10^{7}$ $\mathrm{cfu} / \mathrm{ml}$ after $144 \mathrm{~h}$ of incubation (Table 1). So, a sigmoid growth curve for bottle gourd isolate and pumpkin isolate was obtained (Fig 1).

\section{Standardization of different inoculum density in relation to disease development}

Out of six inoculum densities $\left(10^{4}, 10^{5}, 10^{6}\right.$, $10^{7}, 10^{8}$ and $10^{9} \mathrm{cfu} / \mathrm{ml}$ of both isolates) tested on the plants of bottle gourd and pumpkin. It was observed (Table 2) that when the seedlings of bottle gourd were inoculated with a bacterial suspension having concentration of $1.97 \times 10^{8} \mathrm{cfu} / \mathrm{ml}$ then shortest incubation period (2.00 days) was recorded which was followed by those inoculated with $0.27 \times 10^{9}$ $\mathrm{cfu} / \mathrm{ml}$ (2.33 days) and $1.28 \times 10^{7} \mathrm{cfu} / \mathrm{ml}(2.66$ days). However, all these three treatments were statistically at par with each other. The longest incubation period (4.00 days) was recorded in seedlings inoculated with a bacterial suspension having inoculum density $3.2 \times 10^{4} \mathrm{cfu} / \mathrm{ml}$ which was statistically at par with those inoculated with $6.2 \times 10^{5} \mathrm{cfu} / \mathrm{ml}$ (3.33 days) inoculum density which was further at par with the incubation period of seedlings inoculated with a bacterial suspension having inoculum density of $1.77 \times 10^{6} \mathrm{cfu} / \mathrm{ml}$ (3.00 days). Significantly maximum mean disease severity $(39.65 \%)$ was recorded when the bottle gourd seedlings were inoculated with a bacterial suspension of inoculum density $1.97 \times 10^{8} \mathrm{cfu} / \mathrm{ml}$ followed by those inoculated with a bacterial suspension of concentration $0.27 \times 10^{9} \mathrm{cfu} / \mathrm{ml}$ $(35.70 \%)$. However, an inoculum density of $3.2 \times 10^{4} \mathrm{cfu} / \mathrm{ml}$ incited significantly minimum mean disease severity $(24.62 \%)$ on the bottle gourd seedlings. Irrespective to the inoculum density, significantly minimum mean disease severity $(5.94 \%)$ was recorded on 0 day after disease appearance and significantly maximum mean disease severity $(54.23 \%)$ was recorded after 10 days of disease appearance. It was further noted that there was a significant increase in the disease severity after every two days of observation.

As far as the apparent infection rate was concerned, it was significantly maximum (0.32 per unit per day) in the seedlings inoculated with inoculum density of $1.97 \times 10^{8}$ cfu/ml which was statistically at par with those inoculated with $0.27 \times 10^{9} \mathrm{cfu} / \mathrm{ml}(0.30$ per unit per day), $1.28 \times 10^{7} \mathrm{cfu} / \mathrm{ml}(0.30$ per unit per day) and $1.77 \times 10^{6} \mathrm{cfu} / \mathrm{ml}(0.29$ per unit per day). 
However, the apparent infection rate was found to be minimum in the seedlings inoculated with $3.2 \times 10^{4} \mathrm{cfu} / \mathrm{ml}(0.22$ per unit per day) which was significantly followed by the apparent infection rate in seedlings inoculated with inoculum density of $6.2 \times 10^{5}$ $\mathrm{cfu} / \mathrm{ml}$ (0.27 per unit per day).

As far as the AUDPC in the inoculated seedlings was concerned, it was found to be maximum (3.89) in the seedlings inoculated with $1.97 \times 10^{8} \mathrm{cfu} / \mathrm{ml}$ which did not differ significantly from the AUDPC recorded in the seedlings inoculated with an inoculum density of $0.27 \times 10^{9} \quad \mathrm{cfu} / \mathrm{ml} \quad(3.44)$ and $1.28 \times 10^{7} \mathrm{cfu} / \mathrm{ml}(3.20)$.

Interestingly, the AUDPC in the seedlings inoculated with an inoculum density $3.2 \times 10^{4}$, $6.2 \times 10^{5}$ and $1.77 \times 10^{6} \mathrm{cfu} / \mathrm{ml}$ did not differ with inoculum density of $1.15 \times 10^{8} \mathrm{cfu} / \mathrm{ml}$ which was statistically at par with those inoculated with $0.19 \times 10^{9} \mathrm{cfu} / \mathrm{ml}(3.82)$.

Significantly, being minimum (2.46) in the formerly first concentration $\left(3.2 \times 10^{4} \mathrm{cfu} / \mathrm{ml}\right)$ followed by second (2.67) and third (2.98) concentration.

Data presented in Table 3 depict the incubation period and disease level in case of pumpkin seedlings. Data reveal that the shortest incubation period (4.00 days) was recorded when the seedlings of pumpkin were inoculated with a bacterial suspension having concentration of $1.15 \times 10^{8} \mathrm{cfu} / \mathrm{ml}$ which was statistically at par with those in $0.19 \times 10^{9}$ $\mathrm{cfu} / \mathrm{ml}$ (4.33 days) and $1.02 \times 10^{7} \mathrm{cfu} / \mathrm{ml}$ (4.33 days).

The seedlings inoculated with bacterial suspension of concentration $2.2 \times 10^{4} \mathrm{cfu} / \mathrm{ml}$ exhibited longest incubation period $(6.00$ days) which was statistically at par inoculum density of $1.48 \times 10^{6} \mathrm{cfu} / \mathrm{ml}$ (5.33 days) and $4.3 \times 10^{5} \mathrm{cfu} / \mathrm{ml}$ (5.66 days).
From the table, it is evident that irrespective of days of observation, significantly maximum mean disease severity (38.89\%) was recorded when the pumpkin seedlings were inoculated with a bacterial suspension having inoculum density $1.15 \times 10^{8} \mathrm{cfu} / \mathrm{ml}$ which was statistically at par with those inoculated with $0.19 \times 10^{9} \quad(38.08 \%)$ and $1.02 \times 10^{7} \mathrm{cfu} / \mathrm{ml}(36.43 \%)$.

However, an inoculum density of $2.2 \times 10^{4}$ $\mathrm{cfu} / \mathrm{ml}$ incited significantly minimum mean disease severity $(24.41 \%)$ on the pumpkin seedlings which was followed by $4.3 \times 10^{5}$ $(27.72 \%)$ and $1.48 \times 10^{6} \mathrm{cfu} / \mathrm{ml}(30.93 \%)$. Irrespective to the inoculum density, significantly minimum mean disease severity $(6.66 \%)$ on pumpkin seedlings was recorded on 0 day after symptom appearance and significantly maximum mean disease severity $(57.48 \%)$ was recorded after 10 days of disease appearance and there was a significant increase in the disease severity after every two days of observation.

As far as the apparent infection rate was concerned, it was significantly maximum (0.28 per unit per day) in the seedlings inoculated with inoculum density $1.15 \times 10^{8}$ and $0.19 \times 10^{9} \mathrm{cfu} / \mathrm{ml}$ which was found to be statistically at par with those inoculated with inoculum density of $1.02 \times 10^{7}(0.27$ per unit per day) and $1.48 \times 10^{6} \mathrm{cfu} / \mathrm{ml}(0.27$ per unit per day). However, significantly minimum apparent infection rate (0.22 per unit per day) was recorded in the seedlings inoculated with inoculum density of $2.2 \times 10^{4} \mathrm{cfu} / \mathrm{ml}$. As far as the AUDPC was concerned, it was found to be significantly minimum (2.34) in the seedlings inoculated with an inoculum density of $2.2 \times 10^{4} \mathrm{cfu} / \mathrm{ml}$ followed by those inoculated with $4.3 \times 10^{5} \mathrm{cfu} / \mathrm{ml}$ (2.68) which was statistically at par with seedlings inoculating of $1.48 \times 10^{6} \mathrm{cfu} / \mathrm{ml} \quad$ (2.72). However, maximum (3.86) AUDPC were recorded in the seedlings inoculated. 
Effect of different methods of inoculation on disease development in bottle gourd and pumpkin

The effect of different methods of inoculation on disease development was studied by inoculating a standard concentration $\left(1.9 \times 10^{8}\right.$ $\mathrm{cfu} / \mathrm{ml}$ for bottle gourd and $1.15 \times 10^{8} \mathrm{cfu} / \mathrm{ml}$ for pumpkin isolate) of bacterial suspension obtained in 4.5.2 on 1 month old seedlings of bottle gourd and pumpkin. Data were recorded in terms of the incubation period and disease severity and further calculating apparent infection rate and AUDPC. Data recoded have been presented in Tables 4 and 5.

A perusal of data presented in the Table 4 reveals that among the various methods, the incubation period was minimum (2.33 days) when the seedlings were inoculated by syringe method which was statistically at par with pin prick (2.66 days) and leaf margin (2.66 days) inoculation methods. However, significantly maximum incubation period (7.66 days) was recorded when the seedlings were inoculated with swab inoculation method followed by those inoculated with spray method (6.33 days). As far as, the mean disease severity was concerned, irrespective of the days of observation, it was found to be maximum $(46.33 \%)$ in syringe method of inoculation which was statistically at par with leaf margin inoculation $(43.21 \%)$ and pin prick inoculation (42.00\%). However, significantly minimum mean disease severity (31.87\%) was recorded in swab inoculation method followed by spray inoculation method $(36.78 \%)$.

Irrespective of methods of inoculation, mean disease severity was minimum $(8.15 \%)$ on the day of symptom development (0 day) which increased significantly on each subsequent interval of observation and reached maximum $(65.41 \%)$ after 10 days of disease appearance.
As far as AUDPC in the seedlings of bottle gourd was concerned, it was maximum (4.71) in the syringe inoculation method which was found to be statistically at par with pin prick (4.40) and leaf margin (4.36) methods of inoculation. However, the value of AUDPC in seedlings of bottle gourd was found to be significantly minimum (3.14) which was statistically at par with AUDPC in seedlings inoculated with spray method of inoculation (3.69).

Shortest incubation period was recorded (Table 5) in syringe inoculation (3.33 days) which was statistically at par with pin prick (3.66 days) and leaf margin methods of inoculation (4.66 days). However, maximum incubation period was recorded in swab inoculation (7.33) which was statistically at par with the spray method of inoculation (6.66 days).

As far as disease severity in pumpkin seedlings was concerned, irrespective of days of observation, among the various methods of inoculation, significantly maximum mean disease severity (37.97\%) was recorded in the seedlings inoculated with syringe inoculation method followed by pin prick method of inoculation $(31.17 \%)$ which was statistically at par with mean disease severity in plants inoculated by leaf margin method of inoculation $(29.70 \%)$.

However, significantly minimum mean disease severity (21.47\%) was recorded in the seedling inoculated with swab inoculation. On an average, minimum mean disease severity $(9.50 \%)$ was recorded on the day of symptoms development ( 0 day) which increased significantly on each subsequent interval of observation and reached maximum (54.64\%) after 10 days of disease appearance with respect to method of inoculation. As far as the apparent infection rate was concerned, it was found to be significantly maximum 
(0.30 per unit per day) in seedlings inoculated by pin prick method which was statistically at par with spray inoculation (0.29 per unit per day) and syringe inoculation methods (0.29 per unit per day). However, significantly minimum apparent infection rate $(0.17$ per unit per day) was recorded in the pumpkin seedlings inoculated at leaf margins whereas, significantly minimum (2.08) AUDPC was observed in swab inoculation followed by spray method of inoculation (2.79).

Based on cultural and biochemical characters, the identity of the pathogen was confirmed to be Xanthomonas sp, as the colonies of the pathogen were mucoid, circular, smooth textured and yellow in colour having a diameter of 2-4 $\mathrm{mm}$. The pathogen was found to be Gram-ve, positive for esculin hydrolysis and protein digestion test. These tests were in confirmity with the characters documented by Society of American Bacteriologists (1957) and Schaad and Stall (1988) for genus Xanthomonas. The findings were also in accordance with many researchers who worked on $X$. cucurbitae and reported that the bacterium was positive for esculin hydrolysis and protein digestion test and Gram-ve (Lamichhane et al., 2010; Dutta et al., 2013; Ravanlou and Babadoost, 2015 and Sharma, 2016). All inoculum densities tested were able to induce the disease in test plants but, an inoculum density of range $10^{7} \mathrm{cfu} / \mathrm{ml}$ and above was found to incite significantly higher levels of disease severity and rate of its spread as compared to lower concentrations of bacterial suspension in both bottle gourd and pumpkin isolates.

This indicates that an inoculum density of the range $10^{7} \mathrm{cfu} / \mathrm{ml}$ is the optimum range of inoculum concentration to incite significant amount of disease in two cucurbits under study. The results were in accordance with findings of many workers who have reported that a bacterial concentration of $10^{5}$ to $10^{8}$ $\mathrm{cfu} / \mathrm{ml}$ is able to incite pathogenic reaction in different cucurbit hosts. (Pruvost et al., 2009; Lamichhane et al., 2010; Jarial et al., 2011; Babadoost and Ravanlou, 2012; Dutta et al., 2013; Trueman et al., 2014).

Table.1 Population of bottle gourd and pumpkin isolate of $X$. cucurbitae in relation to time

\begin{tabular}{|c|c|c|c|c|}
\hline \multirow{2}{*}{ Time (h) } & \multicolumn{2}{|c|}{ Bottle gourd isolate } & \multicolumn{2}{c|}{ Pumpkin isolate } \\
\cline { 2 - 5 } & $\mathbf{c f u / m l}$ & $\mathbf{l n} \mathbf{c f u} / \mathbf{m l}$ & $\mathbf{c f u} / \mathbf{m l}$ & ln cfu/ml \\
\hline $\mathbf{0}$ & $3.2 \times 10^{4}$ & 10.37 & $2.2 \times 10^{4}$ & 9.99 \\
\hline $\mathbf{6}$ & $6.2 \times 10^{5}$ & 13.33 & $4.3 \times 10^{5}$ & 12.97 \\
\hline $\mathbf{1 2}$ & $1.77 \times 10^{6}$ & 14.38 & $1.48 \times 10^{6}$ & 14.21 \\
\hline $\mathbf{2 4}$ & $1.28 \times 10^{7}$ & 16.36 & $1.02 \times 10^{7}$ & 16.13 \\
\hline $\mathbf{4 8}$ & $1.97 \times 10^{8}$ & 19.09 & $1.15 \times 10^{8}$ & 18.56 \\
\hline $\mathbf{7 2}$ & $0.27 \times 10^{9}$ & 19.41 & $0.19 \times 10^{9}$ & 19.06 \\
\hline $\mathbf{9 6}$ & $8.4 \times 10^{7}$ & 18.24 & $7.3 \times 10^{7}$ & 18.10 \\
\hline $\mathbf{1 2 0}$ & $3.5 \times 10^{7}$ & 17.37 & $2.7 \times 10^{7}$ & 17.11 \\
\hline $\mathbf{1 4 4}$ & $2.6 \times 10^{7}$ & 17.07 & $1.9 \times 10^{7}$ & 16.75 \\
\hline
\end{tabular}


Table.2 Effect of inoculum density of X. cucurbitae on disease development in bottle gourd

\begin{tabular}{|c|c|c|c|c|c|c|c|c|c|c|}
\hline \multirow{2}{*}{$\begin{array}{c}\text { Inoculum } \\
\text { density }\end{array}$} & \multirow{2}{*}{$\begin{array}{l}\text { Incubation } \\
\text { Period } \\
\text { (days) }\end{array}$} & \multicolumn{7}{|c|}{ Disease severity $(\%)$ after days of symptoms development } & \multirow{2}{*}{$\begin{array}{l}\text { Apparent infection } \\
\text { rate (per unit per } \\
\text { day) }\end{array}$} & \multirow[t]{2}{*}{ AUDPC } \\
\hline & & 0 day & 2 day & 4 day & 6 day & 8 day & 10 day & $\begin{array}{c}\text { Overall } \\
\text { Mean }\end{array}$ & & \\
\hline $3.2 \times 10^{4}$ & 4.00 & $\begin{array}{c}6.00 \\
(14.04)\end{array}$ & $\begin{array}{c}14.00 \\
(21.43)\end{array}$ & $\begin{array}{c}20.00 \\
(26.30)\end{array}$ & $\begin{array}{c}28.0) \\
(31.62)\end{array}$ & $\begin{array}{c}36.83 \\
(37.27)\end{array}$ & $\begin{array}{c}42.89 \\
(40.87)\end{array}$ & $\begin{array}{c}24.62 \\
(28.59)\end{array}$ & 0.22 & 2.46 \\
\hline $6.2 \times 10^{5}$ & 3.33 & $\begin{array}{c}5.66 \\
(13.62)\end{array}$ & $\begin{array}{c}13.00 \\
(21.06)\end{array}$ & $\begin{array}{c}25.33 \\
(30.14)\end{array}$ & $\begin{array}{c}36.00 \\
(36.83)\end{array}$ & $\begin{array}{c}43.03 \\
(40.98)\end{array}$ & $\begin{array}{c}48.32 \\
(44.02)\end{array}$ & $\begin{array}{c}28.56 \\
(31.11)\end{array}$ & 0.27 & 2.67 \\
\hline $1.77 \times 10^{6}$ & 3.00 & $\begin{array}{c}5.33 \\
(13.16)\end{array}$ & $\begin{array}{c}14.66 \\
(22.18)\end{array}$ & $\begin{array}{c}26.00 \\
(30.19)\end{array}$ & $\begin{array}{c}35.55 \\
(36.28)\end{array}$ & $\begin{array}{c}45.55 \\
(42.37)\end{array}$ & $\begin{array}{c}51.94 \\
(46.10)\end{array}$ & $\begin{array}{c}29.84 \\
(31.71)\end{array}$ & 0.29 & 2.98 \\
\hline $1.28 \times 10^{7}$ & 2.66 & $\begin{array}{c}5.33 \\
(13.16)\end{array}$ & $\begin{array}{c}22.66 \\
(28.27)\end{array}$ & $\begin{array}{c}32.22 \\
(34.54)\end{array}$ & $\begin{array}{c}39.11 \\
(38.62)\end{array}$ & $\begin{array}{c}48.61 \\
(44.17)\end{array}$ & $\begin{array}{c}56.38 \\
(48.65)\end{array}$ & $\begin{array}{c}34.05 \\
(34.57)\end{array}$ & 0.30 & 3.20 \\
\hline $1.97 \times 10^{8}$ & 2.00 & $\begin{array}{c}7.33 \\
(15.67)\end{array}$ & $\begin{array}{c}22.66 \\
(28.27)\end{array}$ & $\begin{array}{c}33.58 \\
(35.39)\end{array}$ & $\begin{array}{c}47.50 \\
(43.54)\end{array}$ & $\begin{array}{c}58.89 \\
(50.14)\end{array}$ & $\begin{array}{c}67.95 \\
(55.52)\end{array}$ & $\begin{array}{c}39.65 \\
(38.09)\end{array}$ & 0.32 & 3.89 \\
\hline $0.27 \times 10^{9}$ & 2.33 & $\begin{array}{c}6.00 \\
(14.04)\end{array}$ & $\begin{array}{c}24.00 \\
(29.27)\end{array}$ & $\begin{array}{c}32.78 \\
(34.90)\end{array}$ & $\begin{array}{c}42.69 \\
(40.77)\end{array}$ & $\begin{array}{c}50.83 \\
(45.46)\end{array}$ & $\begin{array}{c}57.89 \\
(49.53)\end{array}$ & $\begin{array}{c}35.70 \\
(35.66)\end{array}$ & 0.30 & 3.44 \\
\hline $\begin{array}{c}\text { Over all } \\
\text { Mean }\end{array}$ & & $\begin{array}{c}5.94 \\
(13.95)\end{array}$ & $\begin{array}{c}18.50 \\
(25.08)\end{array}$ & $\begin{array}{c}28.32 \\
(31.91)\end{array}$ & $\begin{array}{c}38.14 \\
(37.94)\end{array}$ & $\begin{array}{c}47.29 \\
(43.40)\end{array}$ & $\begin{array}{c}54.23 \\
(47.45)\end{array}$ & & & \\
\hline $\mathbf{C D}_{0.05}$ & 0.73 & & & Inoculum & $\begin{array}{r}\mathrm{I} \\
\mathrm{I} \\
\text { ensity } \times \mathrm{I}\end{array}$ & $\begin{array}{l}\text { culum de } \\
\text { ease sev } \\
\text { ease sev }\end{array}$ & $\begin{array}{l}i t y=2.71 \\
\text { ity }=2.71 \\
\text { ty }=4.68\end{array}$ & & 0.05 & 0.72 \\
\hline SE & 0.23 & & & Inoculun & $\begin{array}{r}\mathrm{I} \\
\mathrm{I} \\
\text { ensity } \times \mathrm{I}\end{array}$ & $\begin{array}{l}\text { culum de } \\
\text { ease sev } \\
\text { ease sev }\end{array}$ & $\begin{array}{l}\text { ity }=1.35 \\
\text { ty }=1.35 \\
t y=3.32\end{array}$ & & 0.02 & 0.33 \\
\hline
\end{tabular}

Figures in parentheses are angular/arcsine transformed values 
Table.3 Effect of inoculum density on disease development in pumpkin

\begin{tabular}{|c|c|c|c|c|c|c|c|c|c|c|}
\hline \multirow{2}{*}{$\begin{array}{l}\text { Inoculum } \\
\text { Density }\end{array}$} & \multirow{2}{*}{$\begin{array}{l}\text { Incubation } \\
\text { Period } \\
\text { (days) }\end{array}$} & \multicolumn{6}{|c|}{ Disease severity (\%) after days of disease development } & \multirow[b]{2}{*}{$\begin{array}{l}\text { Over all } \\
\text { mean }\end{array}$} & \multirow{2}{*}{$\begin{array}{c}\text { Apparent } \\
\text { infection rate } \\
\text { (per unit per } \\
\text { day) }\end{array}$} & \multirow[t]{2}{*}{ AUDPC } \\
\hline & & 0 day & 2 day & 4 day & 6 day & 8 day & 10 day & & & \\
\hline $2.2 \times 10^{4}$ & 6.00 & $\begin{array}{c}8.66 \\
(16.74)\end{array}$ & $\begin{array}{c}12.00 \\
(20.08)\end{array}$ & $\begin{array}{c}15.55 \\
(23.12)\end{array}$ & $\begin{array}{c}27.41 \\
(31.55)\end{array}$ & $\begin{array}{c}36.93 \\
(37.39)\end{array}$ & $\begin{array}{c}45.94 \\
(42.65)\end{array}$ & $\begin{array}{c}24.41 \\
(29.49)\end{array}$ & 0.22 & 2.34 \\
\hline $4.3 \times 10^{5}$ & 5.66 & $\begin{array}{c}6.66 \\
(14.79)\end{array}$ & $\begin{array}{c}13.33 \\
(21.07)\end{array}$ & $\begin{array}{c}21.11 \\
(27.12)\end{array}$ & $\begin{array}{c}31.11 \\
(33.84)\end{array}$ & $\begin{array}{c}40.44 \\
(39.46)\end{array}$ & $\begin{array}{c}53.65 \\
(47.07)\end{array}$ & $\begin{array}{c}27.72 \\
(30.56)\end{array}$ & 0.24 & 2.68 \\
\hline $1.48 \times 10^{6}$ & 5.33 & $\begin{array}{c}8.00 \\
(16.07)\end{array}$ & $\begin{array}{c}16.00 \\
(23.56)\end{array}$ & $\begin{array}{c}25.55 \\
(30.22)\end{array}$ & $\begin{array}{c}37.03 \\
(37.43)\end{array}$ & $\begin{array}{c}44.44 \\
(41.78)\end{array}$ & $\begin{array}{c}54.65 \\
(47.59)\end{array}$ & $\begin{array}{c}30.93 \\
(32.78)\end{array}$ & 0.27 & 2.72 \\
\hline $1.02 \times 10^{7}$ & 4.33 & $\begin{array}{c}9.33 \\
(17.75)\end{array}$ & $\begin{array}{c}25.33 \\
(30.19)\end{array}$ & $\begin{array}{c}32.88 \\
(34.90)\end{array}$ & $\begin{array}{c}40.25 \\
(39.29)\end{array}$ & $\begin{array}{c}49.55 \\
(44.73)\end{array}$ & $\begin{array}{c}61.22 \\
(51.50)\end{array}$ & $\begin{array}{c}36.43 \\
(36.39)\end{array}$ & 0.27 & 2.96 \\
\hline $1.15 \times 10^{8}$ & 4.00 & $\begin{array}{c}10.66 \\
(19.03)\end{array}$ & $\begin{array}{c}18.66 \\
(25.48)\end{array}$ & $\begin{array}{c}36.91 \\
(37.31)\end{array}$ & $\begin{array}{c}43.22 \\
(41.06)\end{array}$ & $\begin{array}{c}56.67 \\
(48.83)\end{array}$ & $\begin{array}{c}67.22 \\
(55.09)\end{array}$ & $\begin{array}{c}38.89 \\
(37.80)\end{array}$ & 0.28 & 3.86 \\
\hline $0.19 \times 10^{9}$ & 4.33 & $\begin{array}{c}8.66 \\
(17.09)\end{array}$ & $\begin{array}{c}24.66 \\
(29.73)\end{array}$ & $\begin{array}{c}35.95 \\
(36.82)\end{array}$ & $\begin{array}{c}43.11 \\
(41.09)\end{array}$ & $\begin{array}{c}53.80 \\
(47.16)\end{array}$ & $\begin{array}{c}62.31 \\
(52.11)\end{array}$ & $\begin{array}{c}38.08 \\
(37.32)\end{array}$ & 0.28 & 3.82 \\
\hline $\begin{array}{c}\text { Over all } \\
\text { mean }\end{array}$ & & $\begin{array}{c}8.66 \\
(16.91)\end{array}$ & $\begin{array}{c}18.33 \\
(25.02)\end{array}$ & $\begin{array}{c}27.99 \\
(31.58)\end{array}$ & $\begin{array}{c}37.02 \\
(37.37)\end{array}$ & $\begin{array}{c}46.97 \\
(43.23)\end{array}$ & $\begin{array}{c}57.48 \\
(49.34)\end{array}$ & & & \\
\hline $\mathrm{CD}_{0.05}$ & 0.84 & & & & & ulum dens & $\begin{array}{l}\text { Inoculum } \\
\text { Disease } \\
\times \text { Disease }\end{array}$ & $\begin{array}{l}\text { sity }=2.08 \\
\text { erity }=2.08 \\
\text { erity }=3.58\end{array}$ & 0.04 & 0.78 \\
\hline SE & 0.27 & & & & & ulum dens & $\begin{array}{l}\text { Inoculum } \\
\text { Disease } \\
\times \text { Disease }\end{array}$ & $\begin{array}{l}\text { sity }=0.73 \\
\text { rrity }=0.73 \\
\text { arity }=1.80\end{array}$ & 0.02 & 0.25 \\
\hline
\end{tabular}


Table.4 Effect of different methods of inoculation on disease development in bottle gourd

\begin{tabular}{|c|c|c|c|c|c|c|c|c|c|c|}
\hline \multirow{2}{*}{$\begin{array}{l}\text { Inoculation } \\
\text { methods }\end{array}$} & \multirow{2}{*}{$\begin{array}{c}\text { Incubation } \\
\text { period (days) }\end{array}$} & \multicolumn{6}{|c|}{ Disease severity (\%) after days of disease development } & \multirow{2}{*}{$\begin{array}{l}\text { Overall } \\
\text { mean }\end{array}$} & \multirow{2}{*}{$\begin{array}{l}\text { Apparent } \\
\text { infection } \\
\text { rate (per } \\
\text { unit per day) }\end{array}$} & \multirow[t]{2}{*}{ AUDPC } \\
\hline & & 0 day & 2 day & 4 day & 6 day & 8 day & 10 day & & & \\
\hline Leaf margins & 2.66 & $\begin{array}{c}6.20 \\
(14.27)\end{array}$ & $\begin{array}{c}25.00 \\
(29.91)\end{array}$ & $\begin{array}{c}40.6 \\
(39.60)\end{array}$ & $\begin{array}{c}52.32 \\
(46.31)\end{array}$ & $\begin{array}{c}61.11 \\
(51.40)\end{array}$ & $\begin{array}{c}73.96 \\
(59.31)\end{array}$ & $\begin{array}{c}43.21 \\
(40.14)\end{array}$ & 0.34 & 4.36 \\
\hline $\begin{array}{c}\text { Swab } \\
\text { inoculation }\end{array}$ & 7.66 & $\begin{array}{c}9.43 \\
(17.38)\end{array}$ & $\begin{array}{c}16.00 \\
(22.47)\end{array}$ & $\begin{array}{c}25.89 \\
(29.66)\end{array}$ & $\begin{array}{c}36.03 \\
(35.93)\end{array}$ & $\begin{array}{c}48.93 \\
(44.34)\end{array}$ & $\begin{array}{c}54.98 \\
(47.86)\end{array}$ & $\begin{array}{c}31.87 \\
(32.94)\end{array}$ & 0.30 & 3.14 \\
\hline $\begin{array}{l}\text { Syringe } \\
\text { method }\end{array}$ & 2.33 & $\begin{array}{c}6.30 \\
(14.52)\end{array}$ & $\begin{array}{c}25.53 \\
(30.03)\end{array}$ & $\begin{array}{c}45.84 \\
(42.42)\end{array}$ & $\begin{array}{c}60.55 \\
(51.15)\end{array}$ & $\begin{array}{c}65.05 \\
(53.79)\end{array}$ & $\begin{array}{c}74.74 \\
(59.99)\end{array}$ & $\begin{array}{c}46.33 \\
(41.98)\end{array}$ & 0.39 & 4.71 \\
\hline Pin prick & 2.66 & $\begin{array}{c}8.20 \\
(16.57)\end{array}$ & $\begin{array}{c}27.55 \\
(31.49)\end{array}$ & $\begin{array}{c}41.22 \\
(39.91)\end{array}$ & $\begin{array}{c}51.66 \\
(45.94)\end{array}$ & $\begin{array}{c}57.13 \\
(49.10)\end{array}$ & $\begin{array}{c}66.22 \\
(54.45)\end{array}$ & $\begin{array}{c}42.00 \\
(39.58)\end{array}$ & 0.32 & 4.40 \\
\hline Spray method & 6.33 & $\begin{array}{c}10.67 \\
(18.93)\end{array}$ & $\begin{array}{c}19.04 \\
(25.76)\end{array}$ & $\begin{array}{c}29.99 \\
(33.17)\end{array}$ & $\begin{array}{c}49.72 \\
(44.82)\end{array}$ & $\begin{array}{c}54.16 \\
(47.37)\end{array}$ & $\begin{array}{c}57.14 \\
(49.09)\end{array}$ & $\begin{array}{c}36.78 \\
(36.52)\end{array}$ & 0.30 & 3.69 \\
\hline $\begin{array}{l}\text { Over all } \\
\text { mean }\end{array}$ & & $\begin{array}{c}8.15 \\
(16.34)\end{array}$ & $\begin{array}{c}22.6 \\
(27.93)\end{array}$ & $\begin{array}{c}36.72 \\
(36.95)\end{array}$ & $\begin{array}{c}50.05 \\
(44.83)\end{array}$ & $\begin{array}{c}57.28 \\
(49.20)\end{array}$ & $\begin{array}{c}65.41 \\
(54.14)\end{array}$ & & & \\
\hline $\mathbf{C D}_{0.05}$ & 1.06 & \multicolumn{7}{|c|}{$\begin{array}{r}\text { Inoculation methods }=3.58 \\
\text { Disease severity }=3.93 \\
\text { oods } \times \text { Disease severity }=6.19\end{array}$} & 0.12 & 0.93 \\
\hline SE & 0.33 & \multicolumn{7}{|c|}{$\begin{array}{r}\text { Inoculation methods }=1.26 \\
\text { Disease severity }=1.38 \\
\text { methods } \times \text { Disease severity }=3.09\end{array}$} & 0.02 & 0.42 \\
\hline
\end{tabular}

Figures in parentheses are angular/arcsine transformed values 
Table.5 Effect of different methods of inoculation on disease development in pumpkin

\begin{tabular}{|c|c|c|c|c|c|c|c|c|c|c|}
\hline \multirow[b]{2}{*}{$\begin{array}{l}\text { Methods of } \\
\text { inoculation }\end{array}$} & \multirow[b]{2}{*}{$\begin{array}{l}\text { Incubation } \\
\text { period } \\
\text { (days) }\end{array}$} & \multicolumn{7}{|c|}{ Disease severity (\%) after days of symptom development } & \multirow{2}{*}{$\begin{array}{l}\text { Apparent } \\
\text { infection } \\
\text { rate } \\
\text { (per unit } \\
\text { per day) }\end{array}$} & \multirow[b]{2}{*}{ AUDPC } \\
\hline & & 0 day & 2 day & 4 day & 6 day & 8 day & 10 day & $\begin{array}{c}\text { Overall } \\
\text { mean }\end{array}$ & & \\
\hline $\begin{array}{c}\text { Leaf } \\
\text { margin } \\
\text { inoculation }\end{array}$ & 4.66 & $\begin{array}{c}13.33 \\
(21.18)\end{array}$ & $\begin{array}{c}16.16 \\
(23.60)\end{array}$ & $\begin{array}{c}18.83 \\
(25.55)\end{array}$ & $\begin{array}{c}28.77 \\
(32.36)\end{array}$ & $\begin{array}{c}43.33 \\
(41.14)\end{array}$ & $\begin{array}{c}57.97 \\
(49.58)\end{array}$ & $\begin{array}{c}29.70 \\
(32.24)\end{array}$ & 0.17 & 2.83 \\
\hline $\begin{array}{c}\text { Swab } \\
\text { inoculation }\end{array}$ & 7.33 & $\begin{array}{c}11.00 \\
(18.63)\end{array}$ & $\begin{array}{c}12.20 \\
(19.95)\end{array}$ & $\begin{array}{c}15.11 \\
(22.29)\end{array}$ & $\begin{array}{c}20.64 \\
(26.72)\end{array}$ & $\begin{array}{c}29.99 \\
(32.84)\end{array}$ & $\begin{array}{c}39.99 \\
(38.97)\end{array}$ & $\begin{array}{c}21.47 \\
(26.57)\end{array}$ & 0.22 & 2.08 \\
\hline $\begin{array}{c}\text { Syringe } \\
\text { inoculation }\end{array}$ & 3.33 & $\begin{array}{c}11.06 \\
(18.77)\end{array}$ & $\begin{array}{c}20.91 \\
(26.96)\end{array}$ & $\begin{array}{c}34.09 \\
(35.65)\end{array}$ & $\begin{array}{c}43.80 \\
(41.40)\end{array}$ & $\begin{array}{c}52.35 \\
(46.33)\end{array}$ & $\begin{array}{c}65.59 \\
(54.10)\end{array}$ & $\begin{array}{c}37.97 \\
(37.20)\end{array}$ & 0.29 & 3.68 \\
\hline $\begin{array}{l}\text { Pin prick } \\
\text { inoculation }\end{array}$ & 3.66 & $\begin{array}{c}6.53 \\
(14.74)\end{array}$ & $\begin{array}{c}19.33 \\
(25.36)\end{array}$ & $\begin{array}{c}24.12 \\
(29.36)\end{array}$ & $\begin{array}{c}35.57 \\
(36.58)\end{array}$ & $\begin{array}{c}46.00 \\
(42.68)\end{array}$ & $\begin{array}{c}55.50 \\
(48.14)\end{array}$ & $\begin{array}{c}31.17 \\
(32.88)\end{array}$ & 0.30 & 3.11 \\
\hline $\begin{array}{c}\text { Spray } \\
\text { inoculation }\end{array}$ & 6.66 & $\begin{array}{c}5.66 \\
(13.62)\end{array}$ & $\begin{array}{c}14.66 \\
(22.18)\end{array}$ & $\begin{array}{c}22.66 \\
(28.18)\end{array}$ & $\begin{array}{c}30.66 \\
(33.49)\end{array}$ & $\begin{array}{c}40.22 \\
(39.31)\end{array}$ & $\begin{array}{c}54.16 \\
(47.38)\end{array}$ & $\begin{array}{c}28.00 \\
(30.69)\end{array}$ & 0.29 & 2.79 \\
\hline $\begin{array}{c}\text { Overall } \\
\text { mean }\end{array}$ & & $\begin{array}{c}9.50 \\
(17.83)\end{array}$ & $\begin{array}{c}16.65 \\
(23.70)\end{array}$ & $\begin{array}{c}22.90 \\
(28.20)\end{array}$ & $\begin{array}{c}31.89 \\
(34.11)\end{array}$ & $\begin{array}{c}42.38 \\
(40.46)\end{array}$ & $\begin{array}{c}54.64 \\
(47.63)\end{array}$ & & & \\
\hline $\mathbf{C D}_{0.05}$ & 1.78 & & & culation $r$ & Inoc & $\begin{array}{l}\text { ation metl } \\
\text { sease sev } \\
\text { sease sev }\end{array}$ & $\begin{array}{l}\text { ds }=3.10 \\
\text { ity }=3.39 \\
\text { ity }=5.58\end{array}$ & & 0.08 & 0.71 \\
\hline SE & 0.55 & & & culation & $\begin{array}{r}\text { Inoc } \\
\mathrm{L} \\
\text { thods } \times 1\end{array}$ & $\begin{array}{l}\text { ation metl } \\
\text { ease seve } \\
\text { sease sev }\end{array}$ & $\begin{array}{l}\mathrm{ds}=1.09 \\
\mathrm{y}=1.19 \\
\mathrm{ty}=2.67\end{array}$ & & 0.02 & 0.32 \\
\hline
\end{tabular}

Figures in parentheses are angular/arcsine transformed value 


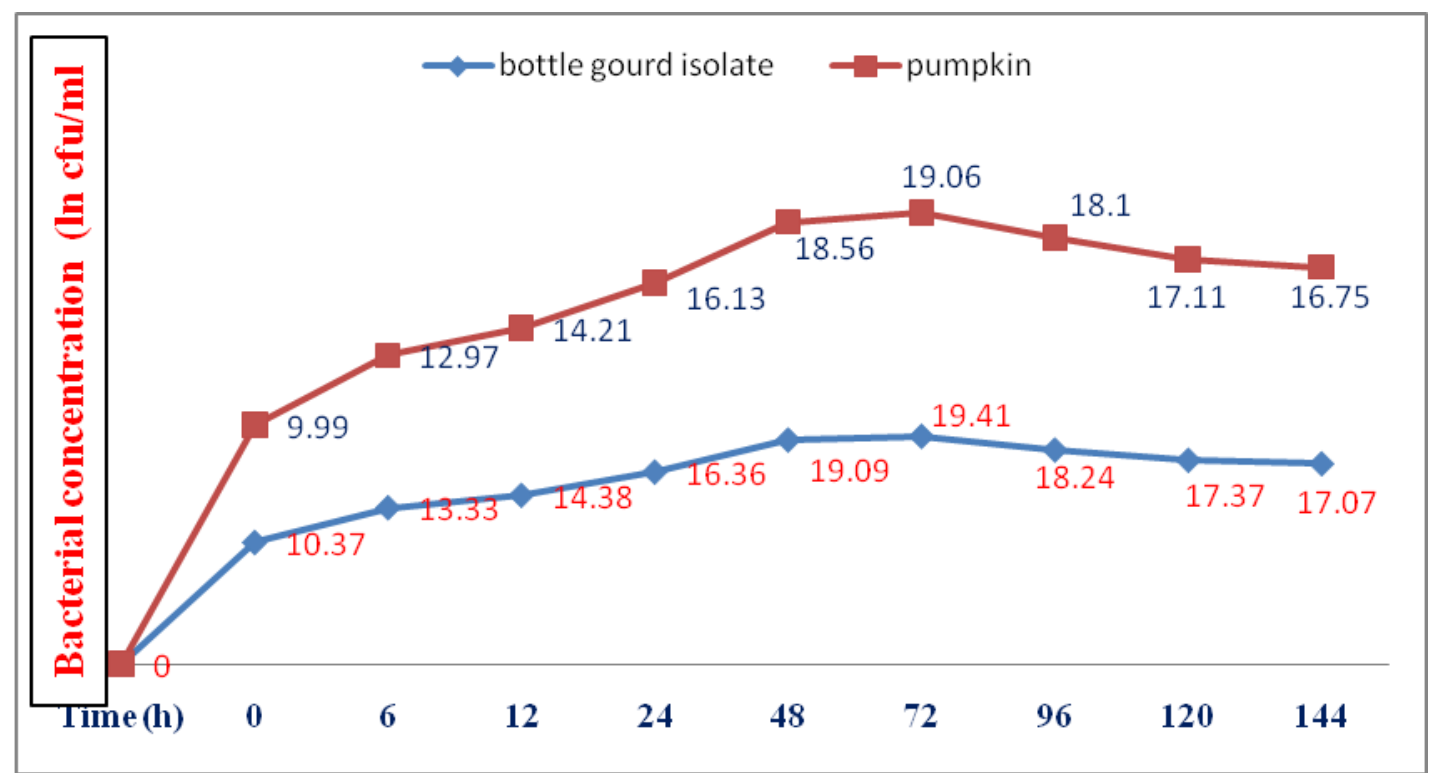

Fig.1 Growth of bottle gourd and pumpkin isolate of $X$. cucurbitae (lncfu/ml) with time

During present studies, syringe inoculation method proved best for the initiation and development of the disease, followed by pin prick and leaf margin methods of inoculation in both bottle gourd and pumpkin isolates of the pathogen. It may be attributed to the fact that the bacterium moves systematically in the plant and thus, the syringe inoculation might have lead to faster spread of the pathogen in the inoculated seedlings resulting in early initiation and faster development of the disease.

In case of pin prick inoculation, wounds were created by pin pricking resulting in easy entry of bacteria and further development of the disease. At leaf margin, hydathodes might have opened the avenues for the entry of bacteria, thus leading to development of disease. In case of swab and spray inoculations the bacteria could enter only through the stomatal openings, thus comparatively lowering the chances of entry of pathogen.

Such type of studies have not been conducted till date on $X$. cucurbitae, so these results cannot be compared with any such work done on X. cucurbitae. However, several workers have conducted inoculation method experiments on other Xanthomonas spp. The results obtained during present studies are in accordance with Patil et al., (2017) who reported infiltration method to be the most suitable for symptom development by $X$. axonopodis pv punicae followed by pin prick method. The results are further supported by the findings of Dhutraj and Soryawansbi (2010) who reported a faster and more pronounced expression of bacterial leaf spot in chilli ( $X$. axonopodis pv vesicatoria) by injection inoculation and pin prick inoculation as compared to smear and spray inoculation techniques.

\section{References}

Ajuru, M., and Nmom, F. (2017). A review on the economic uses of species of cucurbitaceae and their sustainability in Nigeria. American J. Plant Biol. 2(1), 17-24.

Anonymous. (2016). FAO STAT. www.fao.org/faostat.

Anonymous. (2017). Horticulture at a Glance. pp 47.

Babadoost, M., and Ravanlou, A. (2012). Outbreak of Bacterial Spot 
(Xanthomonas cucurbitae) in Pumpkin Fields in Illinois. Plant Dis. 96, 1222.

Babadoost, M., and Zitter, T. A. (2009). Fruit rots of pumpkin: a serious threat to the pumpkin industry. Plant Dis. 93(8), 772-782

Basit, A., Ahmed, I., Rahim, K., and Shafiq, M. (2014). Isolation and identification of phytopathogens from diseased vegetables at District Kohat, Khyber Pakhtunkhwa, Pakistan. J. Curr. Res. Sci. 2, 521-525.

Buttner, D., and Bonas, U. (2010). Regulation and secretion of Xanthomonas virulence factors. FEMS Microbiol Rev. 34(2), 107-133

Dhutraj, D. N., and Soryawansbi, A. P. (2010). Standardization of inoculation techniques for Xanthomonas axonopodis pv. vesicatoria. J. Plant Sci. 5(2), 214-216.

Dutta, B., Gitaitis, R. D., Lewis, K. J., and Langston, D. B. (2013). A new report of Xanthomonas cucurbitae causing bacterial leaf spot of watermelon in Georgia, USA. Plant dis. 97, 556.

El-Hendawy, H. H. (1999). Water stress in cucumber colyledons infected with Xanthomonas campestris pv. cucurbitae. Folia-Microbiologica 44(5), 530-534.

Jarial, K., Dogra, B. S., Mandradia, R. K., Kumar, S., Sharma, D., and Gupta, A. K. (2011). Investigations on a new bacterial disease of bottle gourd in subtropical zone of Himachal Pradesh. Plant Dis. Res. 26(1), 68-75.

Jarial, K., Jarial R. S., and Gupta, S. K. (2015). Bacterial spot (Xanthomonas cucurbitae) of cucurbits: a review. NBU J. Plant Sci. 9(1), 33-39.

Khulakpam, N. S., Singh, V., and Rana, D. K. (2015). Medicinal importance of cucurbitacae crops. Int.Res. J. boil. Sci. 4(6), 1-3.

Lamichhane, J. R., Varvaro, L., and Balestra,
G. M. (2010). Bacterial leaf spot caused by Xanthomonas cucurbitae reported on pumpkin in Nepal. New Dis. Rep. 22, 20.

Larazev, A. M. (2009). Diseases: Xanthomonas campestris pv.cucurbitae (Bryan) Dye-bacterial leaf spot of cucurbits. In: 2003-2009 Project "Interactive agricultural ecological Atlas of Russia and neighbouring countries: economic plants and their diseases, pests and weeds". http://www.agroatlas.ru.

Mitchell, D. J. (1978). Relationships of inoculum levels of several soil borne species of Phytophthora and Pythium to infection of several hosts. Phytopathol. 68,1754-1759.

Patil, A. G., Ambadkar, C. V., Kashid, V. S., and Navgire, K. D. (2017). Standardization of methods for pathogenicity of pomegranate bacterial blight caused by Xanthomonas axonopodsis pv. punicae. J. Pharmacogn. Phytochem. 6(5), 17631765.

Pruvost, O., Robène-Soustrade, I., Ah-You, N., Jouen, E., Boyer, C., Wuster, G., Hostachy, B., Napoles, C., and Dogley, W. (2008). First report of Xanthomonas campestris pv. cucurbitae causing bacterial leaf spot of pumpkin in Reunion Island. Plant Dis. 92(11), 1591.

Pruvost, O., Robène-Soustrade, I., Ah-You, N., Jouen, E., Boyer, C., Wuster, G., Hostachy, B., Napoles, C., and Dogley, W. (2009). First report of Xanthomonas cucurbitae causing bacterial leaf spot of watermelon in the Seychelles. Plant Dis. 93(6), 671.

Ravanlou, A. and Babadoost, M. (2015). Development of Bacterial Spot, Incited by Xanthomonas cucurbitae, in Pumpkin Fields. Horti. Sci. 50(5), 714720.

Robbs, C. F., Kumura, D., and Barbosa, G. A. 
A. (1972). Bacterial blight of squash, a disease new to Brazil. Arquivos do Universidade federal Rural do Rio de Janeiro 2(2), 105-106.

Salamanca, L. R. (2014). Bacterial Diseases of pumpkins: an old enemy and an emerging bacterial disease. Michigan State University Extension Bulletin. http://msue.anr.msu.edu.

Schhad, N. W., and Stall, R. E. (1988). Xanthomonas In: Laboratory Guide for Identification of Plant Pathogenic Bacteria by N.W. Schaad (ed.). American Pythopathogical Society, St. Paul, Minnesota. pp 81-94.

Shanner, G., and Finney, R. E. (1977). The effect of nitrogen fertilization on the expression of slow mildewing resistance in knox wheat. Phytopathol. 67, 10511056

Sharma, R. R. (2016). Integrated Management of Bacterial Spot of Bottle Gourd Caused By Xanthomonas cucurbitae.
M.Sc. Thesis. Sher-e-Kashmir University of Agricultural Sciences \& Technology of Jammu Main Campus, Chatha, Jammu-180009, 81 p.

Society of American Bacteriologists. (1957). Mannual of Microbiological Methods. New York:McGraw Hill Book Company, $31 \mathrm{p}$.

Taketani, K., Tamura, M., and Wakimoto, S. (1976). Studies on fruit spot of prince melon III: Scab like spots caused by Xanthomonas cucurbitae (Bryan) Dowson. Proceedings of the Association for Plant Protection of Hokuriku 24, 63-67.

Trueman, C. L., Roddy, E., and Goodwin, P. H. (2014). First report of bacterial spot (Xanthomonas cucurbitae) of pumpkin in Ontario, Canada. New Dis. Rep. 30, 8.

Van der Plank, J. E. (1963). Plant disease: epidemics and control. New York: Academic Press, 349 p.

\section{How to cite this article:}

Sujata Kumari, Kumud Jarial and Jarial. R. S. 2020. Effect of Inoculum Density and Methods of Inoculation on the Development of Bacterial Leaf Spot of Bottle Gourd and Pumpkin caused by Xanthomonas cucurbitae. Int.J.Curr.Microbiol.App.Sci. 9(06): 1358-1371. doi: https://doi.org/10.20546/ijcmas.2020.906.168 